\author{
Renata PRZYGODZKA, PhD, Professor of the University of Bialystok \\ Faculty of Economics and Management, University of Bialystok \\ e-mail: r.przygodzka@uwb.edu.pl
}

DOI: $10.15290 /$ ose.2017.05.89.09

\title{
EVALUATION VERSUS THE EFFICIENCY OF PUBLIC POLICIES
}

\begin{abstract}
Summary
The article discusses the importance of evaluation in shaping effective public policies. Its purpose is to answer the question of whether and in what conditions evaluations can be a tool for improving the efficiency of public policies. The article has a theoretical nature and is based on studies of both domestic and foreign literature. The analysis presented in the paper shows that from a theoretical point of view the evaluation (along with its methodology and analytical tools) can be an effective instrument for improving the efficiency of public policies. In practice, however, this efficiency mainly depends on such factors as: the model of governance or the mentality of public administration representatives.
\end{abstract}

Key words: evaluation, public policies, efficiency

JEL Classification: H43, H50, H83

\section{Introduction}

The problem related to the improvement of the efficient functioning of state and its institutions is subject of many social sciences, including the sciences related to administration, public policy, public management and sociology. This subject is also important for economics and, in particular, for its sub-discipline - public sector economics. Its main dilemma regards the unlimited character of needs which occurs simultaneously with limited possibilities of satisfying them - both with regards to the entire societies and an individual. The dilemma in equal terms regards the mechanism of market allocation and the allocation realized by the state. The discussion regarding the role of market and state in the theory of economics has taken place for more than two hundred years. Using certain simplification, a statement can be made that the discussion divides economists into the supporters of either the former or the latter mechanism of the allocation of resources. The theories regarding market unreliability and state unreliability show that neither the former nor the latter mechanism is perfect. In the first case, the premises for the state intervention include: unreliability of competitors, existence of public goods, external effects, incompleteness of markets, asymmetry of information on the microeconomic level as well as unemployment, inflation or unequal economic development 
on the macroeconomic level. In the second case, on the other hand, the unreliability of state is expressed, among others, by bureaucratic monopoly, corruption, nepotism, lack of responsibility of politicians and excessive public spending that constitute the reasons for reducing the role of state in economy. The relations between state and market are constantly evolving. However, J. Hausner appears to be right claiming that "economics may not function effectively without state activity, whereas state may not function without effective economics" [Hausner, 2008, p. 78].

Assuming that a practical expression of the state's intervention into economy lies in public policies and taking into consideration the fact that in most economies allocation policies formed using the mechanism of public allocation are related to almost half of the created GDP (in the situation of regular increase of the debt level), the assessment of the results and efficiency of public policies is becoming more important.

One of the instruments serving such assessment is evaluation. In many highly developed countries, evaluation has been used for more than 50 years, which is accompanied by scientific output of interdisciplinary character. In Polish reality, evaluation emerged simultaneously with Poland's accession to the European Union. Additionally, even though the usage of this tool is obligatory for the implementation of EU funds, evaluation is relatively rarely a subject of research, especially in the context of the effectiveness of public policies or (on a more general level) in the perspective of the effectiveness of the public sector.

In this perspective the following question arises: whether and in what conditions evaluation may be a tool for improving the efficiency of public policies. This paper, through is an attempt at answering this question through analysis of subject literature.

\section{Concept, methodological bases, functions and typology of evaluation}

In Poland, evaluation became an interesting subject simultaneously with Poland's accession into the European Union and accompanied the process of implementing the structural funds. Adversely, in highly developed countries evaluation became a universal tool along with the attempts to improve the efficiency of the functioning of both state and its institutions. The improvement of the evaluation process and the application of a scientific approach therein resulted in the distinction of a separate sub-discipline with extensive theoretical output. Significant scientists analyzing this phenomenon include: M.C. Alkin, C.A. Christi [2004, 2006, 2013], C.H. Weiss, M.M. Mark [2008], D.M. Mertens, A.T. Wilson [2012], M. Scrivens [1967], D. L. Stufflebeam, A. J. Shinkfield [2007] and R.L. Miller [2010]. In Polish literature the problem of evaluation can be observed, among others, in the publications of the following scientists: J. Górniak [2005; 2007], T. Kierzkowski [2002], K. Olejniczak [2005, 2007, 2008, 2008a, 2008b], A. Haber [2007; 2010], M. Zawicki [2007], I. Reichardt [2011], W. Felcis, Z. Drożdżak, P. Antosz [2012] and R. Sobiech [2008].

In the Dictionary of Polish published by PWN evaluation is defined as "the determination of the value of something" [https://sjp.pwn.pl/sjp/ewaluacja;2557271.html], whereas the Dictionary of Foreign Words defines it as "the estimation, assessment of 
value" [Stownik..., 2001]. K. Olejniczak stresses the fact that recognition of evaluation as assessment is excessively simplified because evaluation ought to be considered as a process in which assessment may (albeit not necessarily) be one of its elements [Olejniczak, 2008, p. 16]. At the same time Olejniczak indicates that, in the most general approach, evaluation denotes "regular socio-economic study that assesses and informs of the quality and value of public programs" [Olejniczak, 2008, p. 17]. Meanwhile, the scientist views evaluation as "a diversified set of methods and activities oriented at critical reflection on the value and quality of public interventions - both the processes of implementing them and their effects [Olejniczak, 2008, p. 19].

Polish Evaluation Association defines evaluation as:

- $\quad$ "assessment of the value of a project using certain criteria with the aim of its improvement, development or better understanding;

- accumulation, analysis and interpretation of data regarding the importance and value of a project while drawing attention to the issues that are essential for stakeholders;

- $\quad$ assessment of the effectiveness, efficiency, influence, stability and conformity of the project in the context of specified goals, comparison of the project results with the initial intentions" [http://pte.org.pl/o-ewaluacji/].

The aforementioned definitions constitute solely an insignificant number of definitions quoted in the subject literature. Most frequently mentioned definitions were formed by such institutions as the World Bank, United Nations or the European Union. In general, these definitions are similar in terms of their main meaning but particular definitions stress those aspects of evaluation that are important from the perspective of a certain organization ${ }^{1}$. Generally, in accordance with the Tavistock Institute publication [The Evaluation of Socio-Economic Development, 2003; Olejniczak, 2008, pp. 22-23] evaluation is assumed to perform the following functions:

- planning of public activities and ensuring the effective use of resources,

- accountability understood as providing documentation confirming the efficient realization of the goals,

- improving the process of implementing public interventions,

- providing knowledge of the conditions and ways of realizing public tasks,

- institutional reinforcement of the entities that realize public policies and programs.

As has been emphasized, evaluation is a form of research; therefore, in order to make evaluation, theories may be applied therein, based on which research is elaborated and conducted and, afterwards, analyzed and interpreted. These theories, in turn, stem

\footnotetext{
In accordance with art. 54 of the Regulation (EU) No 1303/2013 of the European Parliament and of the Council of 17 December 2013 an evaluation is conducted in order to improve the quality of the design and implementation of programs as well as to analyze their efficiency, effectiveness and accuracy. All the above considered, member states shall provide the resources necessary for carrying out the evaluations. Evaluations should be carried out by internal and external experts that are functionally independent from the entities responsible for the program implementation [Regulation,... 2013].
} 
from a various way of understanding the nature of "truth" and "reality" which are characteristic for philosophy debates from thousands of years ago.

In general, social sciences are divided into two main epistemological paradigms: positivism and interpretivism. Positivism is based on natural sciences and implies that objective reality is independent from people's views and opinions. The aim of science is to identify and describe this objective reality and basic natural laws. In social sciences the objectives of research are similar: objective specification of social phenomena and definition of the general social "laws" that constitute the basis for human behavior. Interpretivism or constructivism as the paradigms of social science were described in Max Weber's publication [1949]. Weber claimed that social science ought to analyze the importance of society and social activities. In this perspective, no objective truth or reality exist, but there are various ways of interpreting and understanding social phenomena, depending on the context and ideological positions of various stakeholders.

These crucial methodological approaches are also characteristic for the evaluation theory. According to D.L Stufflebeam [2007], who conducted detailed analysis of the literature, 22 distinct approaches exist. In general, several key approaches are usually highlighted:

- allocation of resources (methods of assessing the effectiveness of using resources),

- standards and goals (methods enabling the specification of success criteria),

- $\quad$ formative (methods enabling the monitoring of interventions and making current changes),

- $\quad$ interpretative (methods enabling the isolation of factors explaining the effects and further impact of interventions),

- participatory (methods enabling the specification of the participation of society or stakeholders) [Sobiech, 2008, p. 53].

The aforementioned methodological approaches are reflected in various types of evaluation. A wide spectrum of these approaches was presented by K. Olejniczak, who divided them in terms of several criteria [2008, pp. 26-35] and presented them in a synthetic way in table 1 .

Taking into consideration the aforementioned methodological approaches and the criterion of a goal, R. Sobiech [2008, p. 53] used the previously quoted publication of the researchers from The Tavistock Institute [The Evaluation of Socio-Economic Development, 2003] to isolate five basic types of evaluation:

- economic evaluation which aims at planning public activities and ensuring the effectiveness of using resources and implements the methods of assessing the effectiveness,

- evaluation of realizing public activities which concentrates on providing documentation confirming the effectiveness of realizing the goals and using the methods that enable specification of the criteria of success of public activities,

- formative evaluation which concentrates on improving the management of public activities and uses methods enabling the monitoring of interventions and making current changes, 
- causative evaluation which aims at explaining the mechanisms of more extensive social change and concentrates on providing knowledge on the conditionings and ways of realizing public activities; it implements methods enabling the isolation of factors explaining the results and greater impact of intervention,

- evaluation of social participation which enables the assessment of institution development, which is related chiefly to the formation of stable relations with its social environment; this evaluation uses methods that enable the specification of participation of public communities or stakeholders in public activities.

\section{Typology of evaluation}

TABLE 1.

\begin{tabular}{|l|l|}
\hline \multicolumn{1}{|c|}{ Criterion of division } & \multicolumn{1}{c|}{ Type of evaluation } \\
\hline Subject of evaluation & Of a project \\
& Of a program \\
Of a policy & Thematic/horizontal \\
& Meta-evaluation \\
\hline General goal of the evaluation & $\begin{array}{l}\text { Formative/Operational } \\
\text { Summative/Strategic }\end{array}$ \\
\hline Moment of conducting the research & Ex ante \\
& Mid-term \\
& On-going \\
& Ex post \\
\hline The way of organizing the research & Internal \\
& External \\
\hline Applied research approach & Experimental and quasi-experimental \\
& Excluding program goals \\
& Participatory \\
& Giving rights to stakeholders \\
& Realistic \\
\hline
\end{tabular}

Source: elaboration on the basis [Olejniczak, 2008, pp. 26-35].

A similar classification was suggested by J. C. Alkin with a group of researchers [Alkin et al., 2006, p. 387] who distinguish evaluation as scientific research, evaluation oriented towards aims, evaluation oriented towards management, evaluation oriented towards professional evaluation and evaluation oriented towards participants.

For the purpose of this paper, a model of evaluation proposed by E. Vedung [2017], taking the perspective of political sciences and, in broader perspective, social sciences into consideration, is of particular interest. For this purpose, Vedung adjusted solutions from the evaluation model adopted by Guba and Lincoln [1981]. While analyzing the types of evaluation models that consider the needs of contractors, Vedung isolated models that concentrate on the material effects of government interventions ${ }^{2}$ and models that

2 Vedung considers the concept of government interventions as both public policies and public programs. 
analyze conformity with the law, validity etc. Vedung defined the former models as substantive (material), whereas the latter models as procedural ones. The substantive models include efficiency models, effectiveness model and professional models. While the former models consider mainly the effects of intervention and are oriented towards the assessment of the realization of goals, results and system elements, expectations of customer or stakeholders, the economic models are oriented towards the assessment of productivity and effectiveness. Hence, they take into consideration both the effects and costs of intervention. Use of classical methods of measuring the effectiveness such as the analysis of costs-benefits, the analysis of costs-efficiency or the methods of planning budget allow to consider evaluation in this aspect to be based on praxeological premises and to serve the assessment of the effectiveness of public policy.

FIGURE 1.

\section{Models of substantive evaluation}

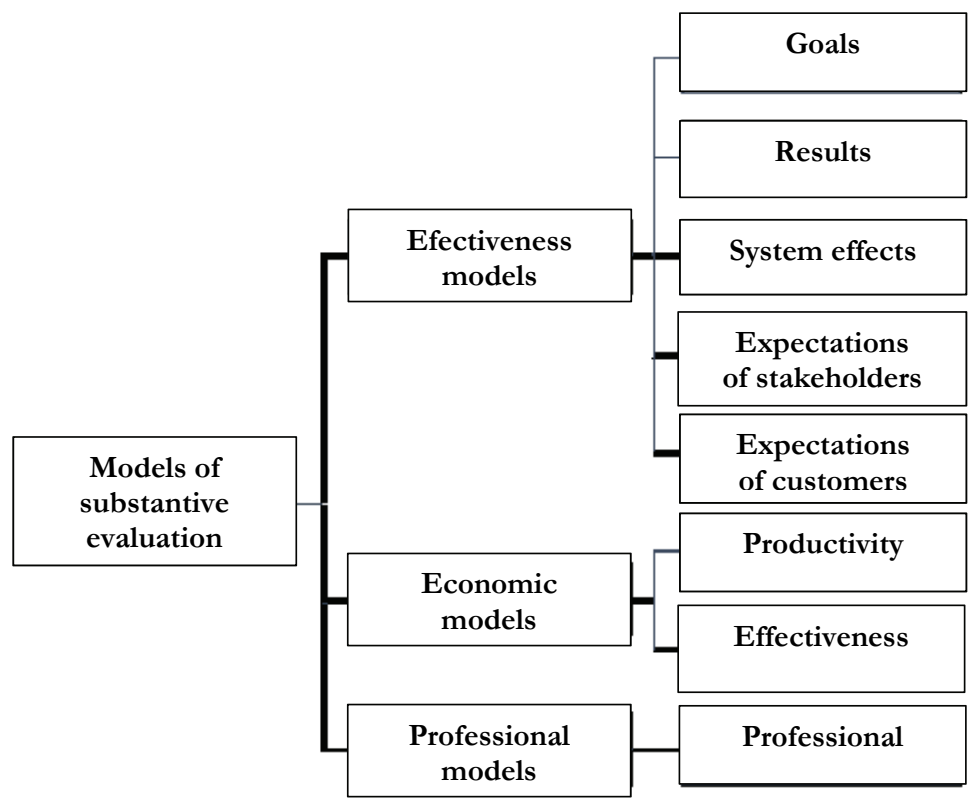

Source: own elaboration on the basis of [Vedung, 2017].

\section{The conceptualization of the term "public policies"}

In the most general perspective, public policies denote all the activities undertaken by the government. Public policy (or policy making) means rational public activity based on specified principles and rules [Woźnicki, 2012, pp. 134-135]. Public policies are perceived in a similar way by $\mathrm{J}$. Hausner who places them on one of four levels of 
realizing policy in general, i.e. on the "functional-technical" level [Hausner, 2008, p. 36]. Hausner also considers it as a specific type of policy realized in various spheres of social existence while using a wide spectrum of instruments such as available resources, the diagnostics of problems, the knowledge of decision-makers, etc. Hence, the concept of public policy may denote the intervention addressed at a certain group of recipients and aiming at either the solution or elimination of the existing problem.

In the theory it is emphasized that the process of forming public policies is characterized by having many stages and cycles [Zybała, 2015, pp. 30-31], i.e. certain sequencing of particular activities exists. Thus, the process may be divided into the following stages:

- definition of the problem and justification of the necessity of solution,

- formulation of policy, i.e. proposing certain solutions,

- obtainment of approval for the suggested solutions and their legitimization,

- implementation and provision of proper resources (financial, human, organizational),

- evaluation of the implemented policy and its correction on the basis of the obtained feedback.

The sequencing of particular stages is presented on figure 2 .

\section{Stage model of public policy shaping}

FIGURE 2.

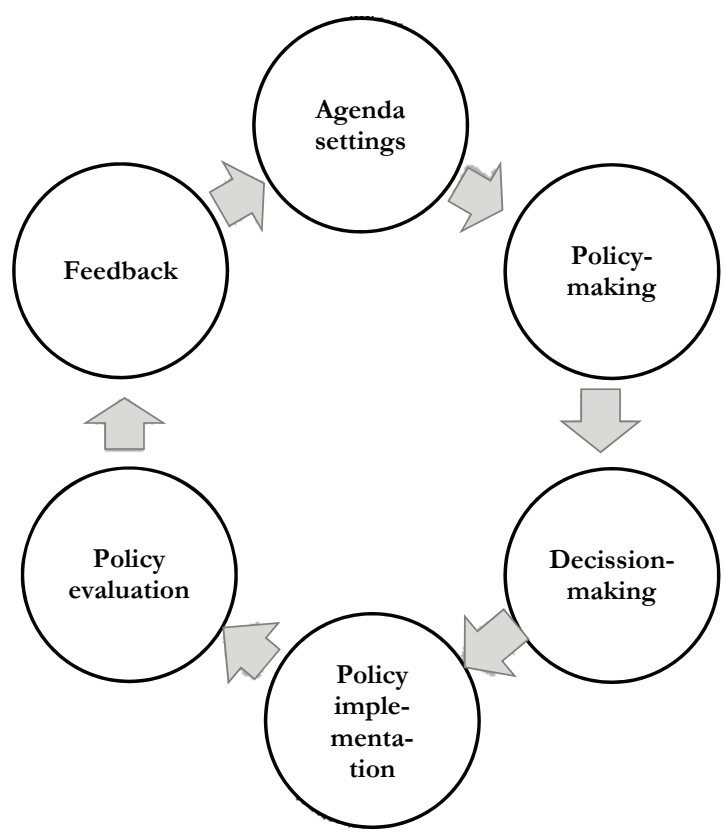

Source: own elaboration on the basis of [Vedung 2017; Szarfenberg 2013]. 
The creation of effective public policy, described by Stiglitz as an efficient and rational policy [Stiglitz, 2004], requires reliability and objectivism in each of the aforementioned stages. Due to the limited scope of this paper, attention ought to be drawn especially to three stages from this group: formulating public policy, evaluating public policy and providing feedback. In the first stage, ten issues crucial for creating effective public policies should be taken into consideration, such as [Stiglitz, 2004] $]^{3}$ :

1. Justification of the purposefulness of a particular policy - this stage is related to analyzing the origins and circumstances in which the policy was created.

2. Specification of the types of market unreliability that the policy ought to counteract - in this stage the sources (reasons)of the necessity of state intervention must be presented. This means the obligation to determine whether the reasons are: an imperfect competition, the existence of public goods, external effects, incomplete markets or incomplete information. In some cases (even when economy meets conditions of Pareto efficiency) the intervention of state may be caused by non-uniform income distribution which is far from the ideal (social equality) or by a individuals' subjective perception of their own welfare.

3. Assessment of the existing solutions alternative to the designed public policy - when the essence of market unreliability is specified, various possibilities of solving the problem should be sought; most frequently the potential state activities in this sphere are divided into three groups, i.e.: public production, private production combined with taxes and subsidies that aim at supporting certain activities or discouraging people from them as well as private production subject to state regulation. Additionally, in each case, methods and directions of allocating goods should be specified.

4. Detailed description of the construction of designed public policy which means mostly the specification of the "access criteria". This stage is of particular importance for economic effectiveness and social equality, since too liberal criteria of granting aid from the state may lead to including excessive number of people into the program. Adversely, the exacerbation of criteria may exclude those in particular need.

5. Attempt to predict the possible reactions of the private sector - this stage implies the assessment of the degree to which demand and supply have changed over short and long period. Due to various reactions related to many conditions, this stage is considered to be one of the most difficult and widely discussed aspects of the analysis of public policies.

6. Analysis of the effects of the policy in terms of the effectiveness - in this stage, specification of the effects of implementation of the policy is of importance, because the policy may be a source of ineffectiveness both during the production and consumption of a certain good.

7. Assessment of the impact of designed public policy on the redistribution of income - in this situation, specifying who gains profits from the policy, has

3 These issues are discussed in detail by J. Stiglitz with reference to the theory of public spending, however, since major part of the expenditures is related to the realization of public policies, these issues, as a logical sequence of actions, may be applied in the process of designing public policy. 
lost or bears the burden of the policy is of importance. Since public policies cause various reactions of the private sector (which is followed by changes of prices), the effects of a certain policy may considerably exceed the range of direct recipients.

8. Analysis of dilemmas observed in the designed policy and concerning the selection between equality and effectiveness. This problem appears during the assessment of all detailed solutions included in its assumptions.

9. Assessment of the designed public policy in reference to the objectives of state policy. Whereas the presented stages of analyzing public policy were dominated by two issues (namely, their impact on economic efficiency and influence on the redistribution of revenues in a society), it is necessary to be aware that the general state policy may comprise much more extensive set of goals.

10. Assessment of the designed public policy through the prism of mechanism of making political decisions existing in the country. This stage is important because it enables specification of the regulations that will apply to the assessed program after the completion of the decision-making process and, therefore, determination of the limits of competences of officials who will be managing this stage.

Vast majority of the presented issues requires application of the instruments of economic analysis using both positive and normative approach. Undoubtedly, taking them into consideration while designing public policy is desired phenomenon, especially in context of specifying alternative costs and the attempt to seek alternative solutions. However, one needs to be aware that such policy does not need to be socially accepted in all situations (unless it is based on the participation of its stakeholders) and would guarantee the achievement of the specified goals (efficiency) and maximization of effects in relation to the expenditures made (rationality). Therefore, there is no guarantee that it would be effective after its implementation.

Therefore, in the process of creation and implementation of public policies, considerable importance is attached particularly to two stages, namely evaluation stage and feedback. The reflections from the previous paragraph allow to consider evaluation with its methodological approaches and a set of instruments as the source of information on whether the implemented policy realizes its main objectives, and, if so, in what way are they achieved, what are the costs and benefits as well as what are the alternative costs and external effects and finally, what is the degree of usefulness for the policy addressees, etc. The data obtained in the process of evaluation constitute the basis for realizing another important stage, namely providing feedback, which is perceived as one of the most significant mechanisms of transparency and accountability of the authorities. However, it is emphasized that the systems of reacting function well only in the environment that is open and cooperative [Brenninkmeijer, 2016, p. 75]. Efficiency is not possible in the situation when the evaluation results and feedback are not beneficial for correction or change of the realized public policy and also when the policy creators and decisionmakers are not interested in them due to the willingness to maintain the status quo. 


\section{The importance of evaluation in the improvement of the effectiveness of public policies}

From the theoretical point of view, assumption can be made that evaluation is one of the key elements of both creating and implementing public policies. This thesis can be confirmed by the stage model of designing public policies presented above. However, from the perspective of increasing the effectiveness of public policies, approach that lays emphasis on the economic aspects is of greater importance.

Therefore, the question posed by M. N. Rothbard [2009, p. 345] can be answered in a positive way only to a certain degree. The issue of "whether an economist who advocates the Wertfrei principle (Wertfrei means free from value - author's note) may express his/her own opinion of public policy" is perceived by Rothbard as follows: "an economist who advocates the Wertfrei principle may adopt two procedures: (1) begin praxeological criticism of incoherent and senseless ethical programs; and (2) display analytical myriads of the consequence of the existence of various political systems and government interventions" [Rothbard, 2009, p. 345 and further]. Additionally, according to Rothbard "in the second perspective, the role of an economist is crucial, provided that the analysis conforms to praxeological principles. In any other case this is the role of an ethicist rather than an economist" [Rothbard, 2009, p. 346]. A. Surdej also emphasizes this, claiming that "public policy in modern state is effective to a small degree if it is not based on good knowledge of economic theory" [Surdej, 2012, p. 17].

If the aforementioned perspective was accepted, an economist ought not to be involved in the evaluation of public policies because evaluation in its essence includes normative approaches, just as it is in case of politics. However, it is necessary to remember that the degree of complexity and mutual relationships between the contemporary economics and politics, market and state is particularly great. Additionally, the role of economics (especially political economics) is to assess the economic effects of political decisions and provide economic justification of the decisions that will be made in the future. This is highlighted by A. Dixit, who writes that "in order to be efficient, consulting must not be solely technical, which means that it may not be based solely on expert's economic opinion. The analysis conducted by such consultant must take into consideration the specific nature of political process. This may cause normative and positive implications. Firstly, an economist needs to conform their own convictions when setting the goals of a particular policy. Advising the government to undertake actions that in economic terms maximize social welfare may prove futile if these decisions may result in fiasco in the subsequent elections. Secondly, even if such economist managed to expand the goals of a politician with the issues related to maximization of social welfare, the calculation of optimal strategy would have to include the analysis of political game, in accordance with which these policies would be created and implemented; otherwise, their aim would not be achieved" [Dixit, 2012, p. 24].

In practice, evaluation research of public policies conducted on the basis of economic models for many reasons encounter numerous difficulties. Firstly, the quantification of the effects of implemented policies is particularly complex, as these effects cannot be measured in financial terms. Secondly, the effects occur with considerable time delay 
that exceeds the time limits specified for evaluation. Thirdly, these effects may have various side effects, not always positive ones. Fourthly, positive effects from the perspective of one group of recipients or perceived in one sector do not necessarily need to be viewed in the same way by another group. In order to be effective, policy needs to conform not only to the postulate of efficiency and rationality, but should also generate as little external effects as possible and be characterized by the low level of alternative costs. In most evaluation models there are usually no analyses of this type.

Despite the aforementioned limitations, considerable progress in using evaluation as the tool for improving public policies in many countries of the Western Europe and the United States of America leads to greater transparency and rationality thereof. The usefulness of evaluation is expanding through adopting new functions. Hence, evaluation is perceived not only as the instrument for the assessment of quality or determination of the cause and effect relation between the adopted intervention and its effects, but also as the instrument serving the improvement of processes, reinforcement of social capital, learning or building a network of cooperation [Olejniczak, Ferry, 2008b, p. 42]. However, according to K. Olejczniczak, despite the so-called evaluation boom, especially in the European Union, a small amount of research on the real effects generated by evaluations is a certain drawback, particularly in terms of determining degree of their influence on public policies, programs, processes, etc. [Olejniczak, Ferry, 2008b, p. 41]. According to F. Kuźnik, this is especially important since "the model public policy of the second decade of the 21st century means bottom-up policy, saving, reductionism, partnership and seeking new development perspectives" [Kuźnik, 2012, p. 104].

Poland, with its experiences related to evaluation studies, is included in the group of countries where the research is developing due to external pressures. Due to these pressures, there are now over 130 entities involved in evaluation on the market [Badania..., 2010], each of which conducted an average of three analyses. The analyses of the level of evaluation culture in Poland indicate several factors that have negative influence on the proliferation of this culture in Poland. The authors of the elaboration [Antosz, Drożdżak, Felcis, 2012, p. 5] included the following factors:

- perception of evaluation analyses by public administration personnel (evaluation as the necessity),

- complexity of the procedure of public procurement,

- the level of detail in the specification of essential conditions of the procurement,

- lack of rules regarding the approval of evaluation reports.

In other words, people, their knowledge and awareness as well as the law are the barriers for achieving higher level of evaluation culture and, thus, for using evaluation in the process of improving the effectiveness of public policies. Similar limitations (viewed from another perspective) were mentioned by A. Zybała. Zybała believes that the processes of shaping public policies in Poland are still perceived as "reserved for the entities of representative democracy and subordinated to its public administration" [Zybała, 2015, p. 32]. According to the author, this is a result of "deeply rooted étatist model of public management" [Zybała, 2015, p. 32], in which there is no place for pluralism and deliberation or participation. At the same time, authorities are not interested in accumulating analytical knowledge or using knowledge of experts. In such model, reduction of the 
set of instruments for creating public policies is beneficial because legislative instruments (albeit ineffective in principle) enable having more control.

\section{Conclusion}

The aim of the paper is an attempt at answering the question of whether and in what conditions evaluation may serve as an instrument of improving the effectiveness of public policies. In the conclusion an answer to this question should be provided.

Undoubtedly, from the theoretical point of view, evaluation, with its methodological bases and a set of instruments characteristic for social sciences, may be useful for increasing the efficiency and rationality of public policies. However, the conditions of its practical implementation have significant impact. Some of them undoubtedly result from the procedures of evaluation study, namely proper selection of a type of evaluation, formulation of questions asked before the analysis, appropriate selection of analytical instruments, etc. However, those more significant conditions have objective character and result mostly from the present model of administration and from human mentality. Lack of openness to cooperation, participation and deliberation, i.e. the reluctance of politicians and clerks to listen to the conclusions drawn from evaluation analyses as well as the unwillingness to improve the realized public policies are factors that considerably reduce the impact of evaluation on the effectiveness of public policies.

Overall, conclusion can be made that the issue of using evaluation in the process of improving the effectiveness of public policies can be included both in the sphere of new sub-discipline, i.e. science related to public policies and in the sphere of public sector economics. The evolution of modern societies entails new problems, the solution to which will require public intervention and creation of new policies. Changes also occur in regard of the roles and expectations of the main recipients and stakeholders of public policies. Therefore, the research conducted in this field will have considerable theoretical, cognitive and utilitarian value.

\section{References}

Alkin M.C., Christi C.A., Rose M., 2006, Communicating evaluation, [in:] Handbook of evaluation: policies, programs and practices, I. Shaw, J.C. Green, M.M. Mark (ed.), Sage, London. Alkin M.C., Christie C.A., 2004, An evaluation theory tree, [in:] Evaluation Roots, M. C. Alkin (ed.), SAGE Publications, Thousand Oaks, CA.

Analiza ekonomiczna w polityce publicznej, 2012, A. Surdej (red.), Wydawnictwo Naukowe Scholar, Warszawa.

Analiza polityki publicznej. Podejścia teoretyczno-metodologiczne, 2013, A. Wojciuk (red.), Instytut Badań Edukacyjnych, Warszawa.

Antosz P., Drożdżak Z., Felcis W., 2012, Kultura ewaluacyjna w Polsce, „Zarządzanie Publiczne", nr 2 (18). 
Badanie potencjatu oraz stanu dotychczasowych prac w ramach jednostek ewaluacyjnych funkejonujacych w Instytucjach Zarzadzajacych oraz Instytucjach Pośredniczacych I i II stopnia w ramach NSRO 2007-2013, 2010, EGO s.c., Warszawa.

Brenninkmeijer A., 2016, Feedback for better performing public sector, „Zarządzanie Publiczne", nr 1 (35).

Christie C.A., Alkin M.C., 2013, An evaluation theory tree, [in:] Evaluation Roots: A Wider Perspective of Theorists' View and Influences, (ed.) M.C. Alkin (2nd Ed), SAGE Publications, Thousand Oaks, CA.

Dixit A., 2012, Ekonomiści jako doradcy polityczni i spoteczni, [w:] Analiza ekonomiczna w polityce publicznej, A. Surdej (red.), Wydawnictwo Naukowe Scholar, Warszawa.

Ewaluacja ex-post. Teoria i praktyka badawcza, 2007, (red.) A. Haber, Polska Agencja Rozwoju Przedsiębiorczości, Warszawa.

Ewaluacja fundussy strukturalnych - perspektywa regionalna, 2007, (red.) S. Mazur, Małopolska Szkoła Administracji Publicznej. Kraków.

Ewaluacja w strategicznym zarz̨qdzaniu publicznym, 2007, (red.) A. Haber, M. Szałaj, Polska Agencja Rozwoju Przedsiębiorczości, Warszawa.

Felcis W., Drożdżak Z., Antosz P., 2012, Użyteczność jako kryterium ewaluacji polityk publicznych, „Zarządzanie Publiczne” nr 1(17), DOI 10.4467/20843968ZP.12.002.0526.

Górniak J., 2005, Ewaluacja jako czynnik. doskonalenia zarzadzania strategicznego w administracji publicznej: projekt SAPER, I konferencja ewaluacyjna - Ewaluacja programów o charakterze społeczno-gospodarcsym finansowanych ₹ funduszy strukturalmych, 16 września 2005, Ministerstwo Gospodarki i Pracy, Polska Agencja Rozwoju Przedsiębiorczości, Warszawa.

Górniak J., 2007, Ewaluacja w cyklu polityk publicznych, [w:] Ewaluacja funduszy strukturalnych - perspektywa regionalna, (red.) S. Mazur, Małopolska Szkoła Administracji Publicznej, Kraków.

Guba E.G., Lincoln Y.S., 1981, Effective evaluation, Jossey-Buss Publishers, San Francisco. Hausner J., 2008, Zarzadzanie publiczne, Wydawnictwo Naukowe Scholar, Warszawa. http://pte.org.pl/o-ewaluacji/ (date of access: 25.07.2017).

https://sjp.pwn.pl/sjp/ewaluacja;2557271.html (date of access: 28.07.2017).

Katz I., Newton B.J., Shona B., Raven M., 2016, Evaluation theories and approaches; relevance for Aboriginal context, Social Policy Research Center, Sydney.

Kierzkowski T., 2002, Ocena (ewvaluacja) programów i projektów o charakterze spoteczno-gospodarcsym w kontekście praystapienia Polski do Unii Europejskiej, Polska Agencja Rozwoju Przedsiębiorczości, Warszawa.

Kuźnik F., 2012, Polityka rozwoju $i$ zarzadzanie ustugami publicznymi w strukturach samorzqdowych, KPZK PAN, Warszawa.

Mark M.M., 2008, Building a better evidence base for evaluation theory: Beyond general calls to a framework of types of research on evaluation, [in:] Fundamental issues in evaluation, N.L. Smith, P. Brandon (ed.), Guilford Press, New York.

Mertens D.M., Wilson A.T., 2012, Program Evaluation Theory and Practice. A Comprehensive Guide, The Guildford Press, New York.

Miller R.L., 2010, Developing standards for empirical examinations of evaluation theory, "American Journal of Evaluation", No. 31. 
Olejniczak K., 2005, Teoria i praktyka ewaluacji w swietle doswiadczeń europejskich, „Studia Regionalne i Lokalne", nr 4 (22).

Olejniczak K., 2007, Ewaluacja jako narzedzie zarzadzania w sektorze publicznym, [w:] Rozwój, region, pržestrzeń, G. Gorzelak, A. Tucholska (red.), Ministerstwo Rozwoju Regionalnego, Warszawa.

Olejniczak K., 2008, Mechanizmy wykorzystania ewaluacji. Studium ewaluacji średniookresowych INTERREG III, Wydawnictwo Naukowe Scholar, Warszawa.

Olejniczak K., 2008a, Wprowadzenie do zagadnień ewaluacji, [w:] Teoria i praktyka interwencii publicznych, K. Olejniczak, M. Kozak, B. Lendzion (red.), Wydawnictwa Akademickie i Profesjonalne, Warszawa.

Olejniczak K., Ferry M., 2008b, Ewaluacja w praktyce sektora publicznego, [w:] Ewaluacja jako standard zarzqdzania w sektorze publicznym, B. Pietras-Goc (red.), Wyższa Szkoła Europejska im. ks. J. Tischnera, Kraków.

Reichart I., 2011, Ewaluacja jako narzedzie analizy polityk publicznych, „Zarządzanie Publiczne", nr 1(13), Zeszyty Naukowe Instytutu Spraw Publicznych UJ.

Rothbard M.N., 2009, Interwencjonizm czyli władza a rynek, Fijorr Publishing Company, Chicago-Warszawa.

Rozporządzenie Parlamentu Europejskiego i Rady (UE) nr 1303/2013 z dnia 17 grudnia 2013 r. ustanawiające wspólne przepisy dotyczące Europejskiego Funduszu Rozwoju Regionalnego, Europejskiego Funduszu Społecznego, Funduszu Spójności, Europejskiego Funduszu Rolnego na rzecz Rozwoju Obszarów Wiejskich oraz Europejskiego Funduszu Morskiego i Rybackiego oraz ustanawiające przepisy ogólne dotyczące Europejskiego Funduszu Rozwoju Regionalnego, Europejskiego Funduszu Społecznego, Funduszu Spójności i Europejskiego Funduszu Morskiego i Rybackiego oraz uchylające rozporządzenie Rady (WE) nr 1083/2006, Dz.U. UE nr L347/320.

Scrivens M., 1967, The methodology of evaluation, [in:] Perspctives of curriculum evaluation, R. W. Tyler, M. Gagne, M. Scrivens (ed.), Rand McNally \& Co, Chicago.

Sobiech R., 2008, Ewaluacja a rozliczalność władzpublicznych, [w:] Ewaluacja jako standard zarzqdzania w sektorze publicznym, B. Pietras-Goc (red.), Wyższa Szkoła Europejska im. ks. J. Tischnera, Kraków.

Stufflebeam D.L., Shinkfield A.J., 2007, Evaluation Theory, Models \& Applications, JosseyBass, San Francisco.

Szarfenberg R., 2013, Nauki o i dla polityki publicznej: podejścia teoretyczno-metodologiczne [w:] Analiza polityki publiçnej, A. Wojciuk (red.), Instytut Badań Edukacyjnych, Warszawa.

The Evaluation of Socio-Economic Development, 2003, Tavistock Institute.

Vedung E., 2017, Public policy and program evaluation, Routledge, New York.

Weber M., 1949, Methodology of social science, $1^{\text {st }}$ ed., Free Press, Glencoe.

Woźnicki J., 2012, Nowa dyscyplina - „nauki o polityce publicznej” usytuowana w dziedzinie nauk spolecznych, „Nauka”, nr 1.

Zawicki M., 2007, Træy plaszczyzny ewaluacij - z.praktyki polskiej administracji publicznej, „Zarządzanie Publiczne”, nr 2 (2).

Zybała A., 2015, Polityka publiczna wobec teorii i jej praktyki w Polsce, „Wrocławskie Studia Politologiczne", nr 15. 